\title{
Descended right superior parathyroid adenoma mimicking as inferior adenoma in primary hyperparathyroidism
}

\author{
Kripa Elizabeth Cherian, ${ }^{1}$ Deepak Thomas Abraham, ${ }^{2}$ Thomas Vizhalil Paul, ${ }^{3}$ \\ Nihal Thomas ${ }^{1}$
}

${ }^{1}$ Department of Endocrinology, Christian Medical College, Vellore, Tamil Nadu, India ${ }^{2}$ Department of Endocrine Surgery, Christian Medical College, Vellore, Tamil Nadu, India Vellore, Tamil Nadu, India

\section{Correspondence to} thomasvpaul@yahoo.com
${ }^{3}$ Endocrinology Department, Christian Medical College, Professor Thomas Vizhalil Paul,

Accepted 13 July 2017

\section{DESCRIPTION}

A 22-year-old woman presented with generalised bony pains over past 2 years. Clinical examination was unremarkable, and blood biochemistry revealed parathyroid hormone (PTH)-dependent hypercalcaemia, suggestive of primary hyperparathyroidism (albumin-corrected calcium $-11 \mathrm{mg} / \mathrm{dL}$ (normal range 8.3-10.4); PTH $-256 \mathrm{pg} / \mathrm{mL}$ (normal range 8-50)). Her creatinine was $0.8 \mathrm{mg} / \mathrm{dL}$ (normal range $0.6-1.2)$ and $25-\mathrm{OH}$ vitamin D level was $31 \mathrm{ng} /$ $\mathrm{mL}(30-75)$. She had low bone mass at distal end of radius $(Z$ score of -2.8$)$ and there was no evidence of renal stones. On localisation, both parathyroid scinitigraphy and ultrasound of neck localised the lesion to right inferior gland (figure $1 \mathrm{~A}, \mathrm{~B}$ ). There were no features of multiple endocrine neoplasia type 1 .

She underwent focused right inferior parathyroidectomy, without intraoperative PTH (IOPTH) assay. Postoperatively, however, she had persistent hyperparathyroidism, and biopsy from the excised lesion revealed thymic tissue with no parathyroid gland. A four-dimensional CT (4D CT) done subsequently helped in accurate localisation to an enlarged descended right superior parathyroid gland (figure 2). At re-exploration, an enlarged superior parathyroid gland, weighing $825 \mathrm{mg}$ was identified posterior to the right recurrent laryngeal nerve (figure 3 ). The adenoma was seen at the lower pole of the right lobe of thyroid and was excised. Her calcium and PTH levels normalised following the surgery.

Involvement of multiple glands or a missed parathyroid adenoma are among the most common causes for persistent hyperparathyroidism. ${ }^{1}$ In the presence of concordant imaging, focused parathyroidectomy without IOPTH assay is an acceptable option in a resource-poor

\section{es CrossMark}

To cite: Cherian $\mathrm{KE}$, Abraham DT, Paul TV, et al. BMJ Case Rep Published Online First: [please include Day Month Year]. doi:10.1136/bcr-2017221364
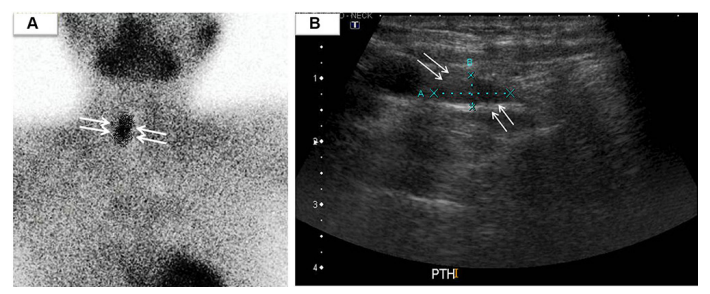

Figure 1 (A)Parathyroid scintigraphy displaying an adenoma at right side. (B) Ultrasound neck showing rightsided adenoma.

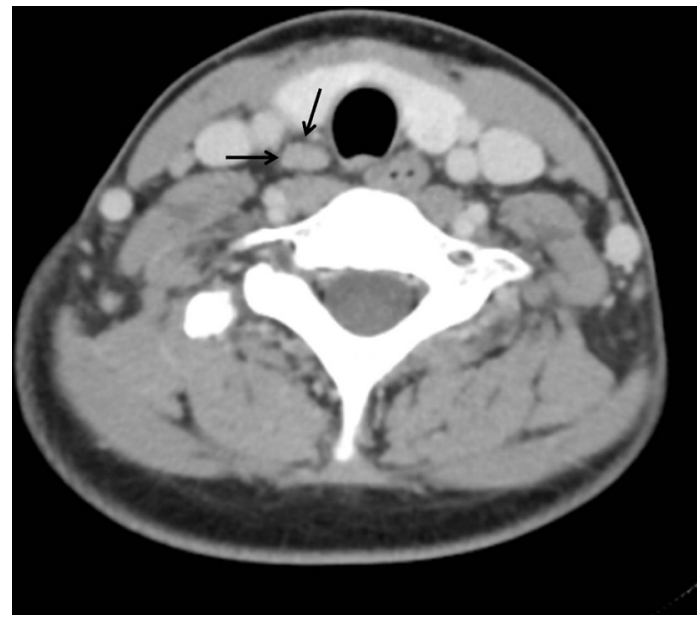

Figure 2 Four-dimensional CT of the neck showing parathyroid adenoma at an inferior location.

setting as in developing country like India'. ${ }^{2}$ During embryologic development, the inferior parathyroid glands migrate with the thymus and are likely to descend in the thymic region in case of mal-development. When the superior parathyroid glands (derived from the fourth pharyngeal pouch) migrate lower than the orthotopic location, they are called overly descended, but they tend to retain the important relation to the recurrent laryngeal nerve (usually located deep or dorsal to it). ${ }^{3}$ Accurate localisation of the parathyroid adenoma is essential to avert a second surgery in the absence of availability of IOPTH. Overly descended superior parathyroid glands may be lower but are deeper than

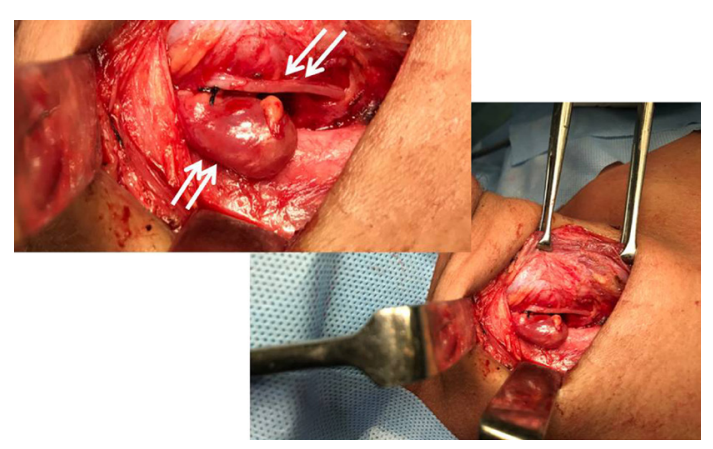

Figure 3 Surgery of the neck displaying parathyroid adenoma and anteriorly located recurrent laryngeal nerve. 


\section{Learning points}

- An overly descended superior parathyroid adenoma may masquerade as an inferior lesion on planar sestamibi images.

- Failure to identify the offending lesion may cause persistent hyperparathyroidism.

- The utilisation of four-dimensional CT in localisation of these lesions reveals the posterior location of these tumours, and intraoperatively, they may be deeper and more posterior, but maintaining its dorsal relation to the recurrent laryngeal nerve.

inferior parathyroid adenomas. Imaging using the 4D CT scan reveals the posterior location of these glands. ${ }^{3}$
Contributors KEC, TVP, DTA: wrote the manuscript. KEC, TVP, DTA and NT: reviewed and approved the manuscript.

Competing interests None declared.

Patient consent Obtained.

Provenance and peer review Not commissioned; externally peer reviewed.

(C) BMJ Publishing Group Ltd (unless otherwise stated in the text of the article) 2017. All rights reserved. No commercial use is permitted unless otherwise expressly granted.

\section{REFERENCES}

1 Lee JC, Mazeh H, Serpell J, et al. Adenomas of cervical maldescended parathyroid glands: pearls and pitfalls. ANZ J Surg 2015;85:957-61.

2 Mownah OA, Pafitanis G, Drake WM, et al. Contemporary surgical treatment of primary hyperparathyroidism without intraoperative parathyroid hormone measurement. Ann $R$ Coll Surg Engl 2015;97:603-7.

3 Duke WS, Vernon HM, Terris DJ. Reoperative parathyroidectomy: overly descended Superior Adenoma. Otolaryngol Head Neck Surg 2016;154:268-71.

Copyright 2017 BMJ Publishing Group. All rights reserved. For permission to reuse any of this content visit

http://group.bmj.com/group/rights-licensing/permissions.

BMJ Case Report Fellows may re-use this article for personal use and teaching without any further permission.

Become a Fellow of BMJ Case Reports today and you can:

- Submit as many cases as you like

- Enjoy fast sympathetic peer review and rapid publication of accepted articles

- Access all the published articles

- Re-use any of the published material for personal use and teaching without further permission

For information on Institutional Fellowships contact consortiasales@bmjgroup.com

Visit casereports.bmj.com for more articles like this and to become a Fellow 